\title{
DETERMINANTS OF DNA YIELD AND QUALITY FROM DIFFERENT NON-INVASIVE SAMPLING METHODS
}

Y.F. Choon, L.P. Karen-Ng, S. Hassan, J. Marhazlinda, R.B. Zain. Determinants of DNA Yield and Quality from Different Non-Invasive Sampling Methods. Annal Dent Univ Malaya 2012; 19(2): 62-65.

\section{ABSTRACT}

Aim: The purpose of this study was to determine the DNA yield and quality from different non-invasive sampling methods and to identify the method which gave the highest DNA yield. Method: Thirty-eight volunteers had been recruited in this study where blood, buccal cells and saliva were collected using various collection techniques. Buccal cells were collected by 1) cytobrush and 2) saline mouth rinsing or "swish". Meanwhile saliva was collected by passive drooling method. Upon processing the white blood cell (WBC), buccal cells and saliva samples, DNA extraction was performed according to the manufacturer's protocol. Quantification and quality (DNA ratio at $\mathrm{A}_{260} / \mathrm{A}_{280}$ ) of the extracted DNA were determined using NanoDropND-1000 ${ }^{\circledR}$. T-test was performed to compare means between DNA obtained from various collection methods. Results: DNA yields from buccal cells collected with cytobrush, "swish", saliva and WBC (mean \pm SD) were $(8.2 \pm 5.9) \mathrm{ng} / \mu \mathrm{l}$, $(28.2 \pm 14.9) \mathrm{ng} / \mu \mathrm{l},(5.9 \pm 9.5) \mathrm{ng} / \mu \mathrm{l}$ and $(105.3 \pm$ 75.0)ng/ $\mu$ l respectively. Meanwhile the mean DNA ratio at $\mathrm{A}_{260} / \mathrm{A}_{280}$ for cytobrush, "swish", saliva and WBC were 2.3, 2.0, 1.7 and 1.8 respectively. Post hoc test with Bonferroni correction suggested that DNA yield from "swish" technique exhibited the least mean different as compared to the DNA extracted from WBC $(p<0.05)$. There was no significant difference in the mean quality of the DNA extracted from WBC, saliva and buccal cells collected in these non-invasive methods $(p=0.323)$. Conclusion: The "swish" technique of obtaining buccal cells yielded the highest amount of DNA and was of the quality of DNA extracted from blood sample.

Key words: buccal cells, non-invasive methods, cytobrush, "swish", saliva, DNA yield, DNA quality

\section{INTRODUCTION}

Buccal cells and saliva are fast becoming an attractive alternatives source of genomic DNA to large scale epidemiological genotyping projects than the more traditional and more invasive phlebotomy-derived DNA from whole blood sample because it is costeffective and yields sufficient quantity and quality DNA for polymerase-chain-reaction (PCR) -based
Original Article

Y.F. Choon', L.P. Karen-Ng², S. Hassan',
J. Marhazlinda ${ }^{3}$ and R.B. Zain 1,2
'Department of Oral Pathology,
Oral Medicine and Periodontology,
Faculty of Dentistry, Univeristy of Malaya,
50603, Kuala Lumpur
E-mail: rosnahmz@um.edu.my
Tel: 03-7967 4896
20ral Cancer Research \& Coordinating Centre
(OCRCC), Faculty of Dentistry,
Univeristy of Malaya, 50603, Kuala Lumpur
32Dental Training Unit, Faculty of Dentistry,
University of Malaya, 50603 Kuala Lumpur,
Malaysia
Corresponding author: Dr Choon Yee Fan

biomarker assays (1-5). In addition, due to the less invasive, simple, and sometimes easy-to-selfadministered methods of collecting the buccal cells, there is a better participation rate from the subjects (6). Methods for collecting the buccal cells, among others, include the use of cytobrush and mouthwash. Saliva has also emerged as a potentially good source of genomic DNA as it contains a vast number of epithelial cells $(7,8)$. While all the aforementioned studies have described successful PCR applications using DNA extracted from buccal cells, none has, thus far, compared all collection methods in the same individual. Hence, it is the objective of this study to compare the yield, and quality, of genomic DNA derived from saliva and buccal cells collected via cytobrush and mouthwash from the same individual.

\section{MATERIALS AND METHODS}

\section{Participants}

Thirty eight in-house staffs and colleagues from the Faculty of Dentistry, University of Malaya, were recruited for this randomized study during the period of $11^{\text {th }}$ to $22^{\text {nd }}$ June 2007.

\section{Sample Collection}

Participants were advised to refrain from brushing their teeth and food/fluid (except water) ingestion, as well as gum-chewing, for at least 1 hour before the sample collection. They were then required to rinse their mouth vigorously with tap water for 5 times before sampling. 
Saliva collection method: passive drool

Saliva was collected from participants by accumulating the saliva at the base of their mouth and tilting their head downwards to allow the secreted saliva to be drawn off from the lower lip. Sterile funnel was attached to the opening of a $15 \mathrm{ml}$ Falcon's tube and gently the saliva was spitted into the tube until $4 \mathrm{ml}$ of saliva was obtained. Samples were then centrifuged for 20 seconds at $2000 \mathrm{rpm}$ in room temperature and $1 \mathrm{ml}$ of the supernatant was transferred as aliquots before storing at $-20^{\circ} \mathrm{C}$.

\section{Buccal cells collection using cytobrush (BCC)}

Participants were instructed to rub their cheeks against the teeth for 30 times before a Cytobrush plus Medscan ${ }^{\circledR}$ was used to brush against the inner cheeks. The brush was then twirled upward and downward with counter pressure for 10 times and left to air dry on the table in the open area for 15 minutes. After that, each of the brush was put inside a $15 \mathrm{ml}$ Falcon's tube and stored immediately at $-80^{\circ} \mathrm{C}$ without any processing. Before DNA extraction, the brush handle was cut off with a wire cutter to $\sim 20 \mathrm{~mm}$ from the bristle and put inside another $15 \mathrm{ml}$ Falcon's tube.

\section{Buccal cells collection using mouthwash (BCS)}

Participants were instructed to rub their cheeks against the teeth for 30 times before normal saline mouthrinse was used. Each participant was instructed to swish $10 \mathrm{ml}$ of the mouth rinse vigorously left and right while rubbing their cheek against the teeth again for 30 seconds. With a sterile funnel, the mouth rinse was expectorated into a $15 \mathrm{ml}$ Falcon's tube slowly. After that the mouth rinse samples were centrifuged at $7500 \mathrm{rpm}$ for 20 minutes. The supernatants were discarded and the pellets were washed with $1.5 \mathrm{ml}$ of TE Buffer, pH8.0 (10mM Tris-HCl, 1nM EDTA).

The samples were finally centrifuged again at 14000rpm for 20 minutes, washed twice, supernatant discarded and the pellets were stored at $-80^{\circ} \mathrm{C}$.

\section{Blood samples collection}

$3 \mathrm{ml}$ of blood from the volunteers were drawn into two blood tubes (plain and EDTA) and the tubes were then carried and transported to the lab for processing on ice packs keeping the blood chilled at $4^{\circ} \mathrm{C}$. In the lab, the blood tubes were centrifuged at $1500 \mathrm{rpm}$ for 15 minutes at room temperature. Serum and plasma were aliquoted $300 \mu \mathrm{l}$ each into $0.5 \mathrm{ml}$ microcentrifuge vials before storage while the white blood cells (WBC) layer was scrapped from the EDTA tube. The WBC was the layer between red blood cells and serum. All serum, plasma and $\mathrm{WBC}$ were stored at $-80^{\circ} \mathrm{C}$.

\section{DNA extraction and Quantification}

DNA of all samples was extracted using QIAamp Blood Mini Kits (Qiagen Inc., Valencia, CA) according to the manufacturers' protocol with some modifications.

\section{Blood, saliva and mouthwash}

$4 \mathrm{ml}$ of PBS was added to the sample and centrifuged to get the pellet. The pellet was then lysed with $20 \mu \mathrm{l}$ of protease and incubated at $56^{\circ} \mathrm{C}$ for 10 minutes. $200 \mu \mathrm{l}$ of ethanol $(100 \%)$ was added to the pellet and then loaded onto a spin column. Before the final centrifugation, incubation at room temperature was extended to 15 minutes to increase DNA yield. DNA was then absorbed, by short centrifugation, onto the QIAamp silica membrane, washed and eluted with $100 \mu 1$ of Buffer AE (supplied together in the QIAamp Blood Mini Kit).

\section{Cytobrush}

DNA extraction from cytobrush was done by incubating with protease at $56^{\circ} \mathrm{C}$ and the period was extended to 30 minutes to make sure that cells, attached to the brush, were lysed fully. The final elution volume obtained was $150 \mu 1$.

\section{Concentration measurements}

DNA quantification was done using NanoDropND-100 spectrophotometer (NanoDrop Technologies, USA). Readings was taken at wavelengths 260 and $280 \mathrm{~nm}$. The ratio of the readings at 260 and $280 \mathrm{~nm}\left(\mathrm{OD}_{260} / \mathrm{OD}_{280}\right)$ provided an estimate of the purity of the DNA. A good quality of DNA would have an $\mathrm{OD}_{260} / \mathrm{OD}_{280}$ ratio between 1.8 to 2.0.

\section{Statistical Analysis}

Data analysis was done using Statistical Package for Social Sciences (SPSS) version 12.0. To compare means of DNA yields and quality between different collection techniques (WBC, saliva, buccal cells via "swish" and cytobrush), t-test was employed and $\mathrm{p}<0.05$ was considered statistical significant. Post hoc test was done using paired t-test with Bonferroni correction was performed to determine which means from these various collection methods differ from each other.

\section{RESULTS}

The mean ( \pm SD) DNA yield from cytobrush, "swish", saliva and WBC was $8.2( \pm 5.9) \mathrm{ng} / \mu \mathrm{l}, 28.2( \pm 14.9)$ $\mathrm{ng} / \mu \mathrm{l}, 5.9( \pm 9.5) \mathrm{ng} / \mu \mathrm{l}$ and $105.3( \pm 75.0) \mathrm{ng} / \mu \mathrm{l}$ respectively.

The mean differences in DNA yield were 77.0ng/ $\mu 1,97.1 \mathrm{ng} / \mu 1$, and $99.4 \mathrm{ng} / \mu \mathrm{l}$ for WBC versus "swish", WBC versus cytobrush and WBC versus saliva respectively. Meanwhile the mean differences in DNA yield for "swish" versus cytobrush were 20.0ng/ $\mu \mathrm{l}$, "swish" versus saliva $22.4 \mathrm{ng} / \mu \mathrm{l}$ and cytobrush versus saliva $2.4 \mathrm{ng} / \mu \mathrm{l}$. DNA yields between WBC and "swish" techniques exhibited the least mean difference $(p=0.000)$ after post hoc test with Bonferroni correction (Table 1). 
Table 1. Comparisons of the DNA yield with different collection techniques

\begin{tabular}{|c|c|c|c|}
\hline \multirow[b]{2}{*}{$\begin{array}{l}\text { Collection } \\
\text { techniques }\end{array}$} & \multicolumn{2}{|c|}{ 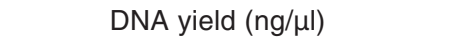 } & \multirow[b]{2}{*}{ P-value ${ }^{a}$} \\
\hline & $\begin{array}{l}\text { Mean } \\
\text { (SD) }\end{array}$ & $\begin{array}{c}\text { Mean differences } \\
(95 \% \mathrm{Cl})\end{array}$ & \\
\hline $\begin{array}{l}\text { WBC } \\
\text { vs BCS }\end{array}$ & $\begin{array}{r}105.3(75.0) \\
28.2(14.9)\end{array}$ & $77.0(51.8-102.3)$ & $0.000^{\mathrm{b}}$ \\
\hline $\begin{array}{l}\text { WBC } \\
\text { vs } B C C\end{array}$ & $\begin{aligned} 105.3 & (75.0) \\
8.2 & (5.9)\end{aligned}$ & $97.1(72.2-122.0)$ & $0.000^{\mathrm{b}}$ \\
\hline $\begin{array}{l}\text { WBC } \\
\text { vs Saliva }\end{array}$ & $\begin{array}{c}105.3(75.0) \\
5.9(9.5)\end{array}$ & $99.4(74.5-124.4)$ & $0.000^{\mathrm{b}}$ \\
\hline $\begin{array}{l}\text { BCS } \\
\text { vs BCC }\end{array}$ & $\begin{array}{r}28.2(14.9) \\
8.2(5.9)\end{array}$ & $20.0(15.0-25.1)$ & $0.000^{\mathrm{b}}$ \\
\hline $\begin{array}{l}\text { BCS } \\
\text { vs Saliva }\end{array}$ & $\begin{array}{r}28.2(14.9) \\
5.9(9.5)\end{array}$ & $22.4(16.9-27.9)$ & $0.000^{b}$ \\
\hline $\begin{array}{l}\text { BCC } \\
\text { vs Saliva }\end{array}$ & $\begin{array}{l}8.2(5.9) \\
5.9(9.5)\end{array}$ & $2.4(-1.6-6.3)$ & $0.241^{b}$ \\
\hline
\end{tabular}

a Repeated measure was done

b Post hoc test using paired t-test with Bonferroni correction

Table 2. Comparisons of the DNA quality with different collection techniques

\begin{tabular}{llcccc}
\hline \multirow{2}{*}{$\begin{array}{l}\text { Collection } \\
\text { techniques }\end{array}$} & \multicolumn{4}{c}{ DNA ratio $\left(\mathrm{A}_{260} / 280\right)$} & \\
\cline { 2 - 5 } & WBC & BCS & BCC & Saliva & \\
\hline Mean (SD) & $1.8(0.1)$ & $2.0(0.3)$ & $2.3(3.1)$ & $1.7(0.9)$ & 0.323 \\
\hline
\end{tabular}

The mean ratio $( \pm \mathrm{SD})$ of the DNA quality were $1.8( \pm 0.1), 2.0( \pm 0.3), 2.3( \pm 3.1)$ and $1.7( \pm 0.9)$ collected from WBC, "swish", cytobrush and saliva respectively (Table 2). However, repeated measure showed no significant differences in DNA quality between different collection techniques $(p=0.323)$. Therefore, no comparison was made between different collection techniques.

\section{DISCUSSION}

Direct comparison among studies are difficult, however, Lum and Le Marchand (9) found an average of $49.7 \mu \mathrm{g}$ of DNA collected from 64 individual of diverse ethnic origins using the "swish" technique. Abouta et al. (1) and Garcia-Closas et al. (7) also found a higher mean amount of DNA collected from the "swish" technique, (15.8 $\mu$ g and $56.7 \mu \mathrm{g}$, respectively) than the amount of DNA collected by using cytobrush (11.95 $\mu \mathrm{g}$ and $2.4 \mu \mathrm{g}$, respectively). Though lower than the aforementioned studies, current study indicated "swish" technique was able to yield a higher amount of DNA with $28.2( \pm 14.9) \mathrm{ng} / \mu \mathrm{l}$ (which equivalent to approximately $5.64 \mu \mathrm{g}$ ), when compared to cytobrush with DNA quantity of only $8.2( \pm 5.9) \mathrm{ng} / \mu \mathrm{l}$ (which equivalent to approximately $1.64 \mu \mathrm{g}$ ). These findings were in concordance with studies conducted by Heath et al. (10) and Garcia-Closas et al. (7) that collection of buccal cells using mouthwash gave greater DNA yields and quality than cytobrush. The higher DNA yield from "swish" technique could possibly include the presence of non-human DNA such as from oral bacteria or food remnants (11) as compared to buccal cells collection through cytobrush only brush from a single site of the inner cheek.

The way in which the buccal cells collected through cytobrush procedure may have shown to affect DNA yield. Cells recovered from improper brushing of the inner cheek could likely be superficial ones in the process of apoptosis. About 30\% of buccal cells collected from persons with healthy, non-inflammatory oral mucosa showed apoptotic signs (12). Hence, DNA from certain individuals may be prone to lower quality and yield.

Previous studies had shown high DNA yield obtained from buccal cells using the "swish" technique $(1,7,9)$. The difference in DNA yield in this study using the "swish" technique compared to previous works carried out by others could be due to the type of mouth rinse used between these studies. The Scope mouthwash which had been used by Abouta et al. (1) and Garcia-Closas et al. (7) was reported to be the most suitable, commercially available mouthwash for obtaining DNA for clinical and research applications (10). The current study however used normal saline mouthrinse $(0.9 \% \mathrm{NaCl})$ as the collecting medium. The normal saline was used because of its minimum chemical composition of the solution and also the mild and gentle taste as mouth rinse. Most of the commercial mouth rinses such as Scope, Listerine, Colgate and Oral-B tasted palatably pungent contained substantial chemicals components (with the presence or absence of alcohol) which may influence the stability of DNA quality and the downstream analysis using the DNA. Study done by Heath et al. (10) has proven that DNA was found to be stable in normal saline at room temperature for up to 4 days. As evidenced in another study in which the subjects used sterile water as the collecting medium, the mean amount of DNA extracted was $4 \mu \mathrm{g} / \mu \mathrm{l}$ (13). Besides, in terms of cost, same amount of normal saline is much cheaper and cost effective than commercial mouth rinses. Because DNA could be stable in normal saline and it's cost effective, normal saline used as mouth rinse was deemed suitable in this study.

The average amount of DNA obtained from saliva in this study was much lower than those reported by a number of other studies. Rylander-Rudqvist and colleagues (14) reported an average DNA yield of $135.9 \mu \mathrm{g}$ from 90 samples while Hansen et al. (6) recorded an average of $10.8 \mu \mathrm{g}$ in their study. Dissimilarity in each individual's oral flora, dietary/ lifestyle habits or because of other reasons such as whether rinsing protocol was performed prior to saliva 
collection and whether actual saliva and not sputum/ phlegm was obtained, all of which could probably explain the differences among these studies. Individuals who smoked often experienced xerostomia which could lead to dry mouth and reduced salivary flow. Storage conditions could also affect the reported lower range in the current study $(16,17)$.

Nevertheless, the quality of the DNA extracted from these non-invasive methods used in this study corresponded to those studies which had also demonstrated the feasibility of using the DNA in PCRbased applications $(1,17)$.

\section{CONCLUSION}

The results showed that "swish" technique employed in this study yielded higher amount of genomic DNA from buccal cells and could be further optimized in the future for PCR-based applications. This noninvasive approach and easily collected source of cellular material as in comparison to blood is definitely more cost effective in a large cohort molecular epidemiological study.

\section{REFERENCES}

1. Abouta S, King IR, Abouta JS, et al. Buccal cell DNA yield, quality and collection costs: comparison of methods for large-scale studies. Cancer Epidemio Biomark Prev. 2002; 11: 1130-133.

2. Walker AH, Najarian D, White DL, et al. Collection of genomic DNA by buccal swabs for polymerasechain-reaction-based biomarker assays. Enviorn Health Perpect. 1999; 107: 517-520.

3. Woo JG, Sun G, Haverbusch M, et al. Quality assessment of buccal versus blood genomic DNA using the Affymetrix $500 \mathrm{~K}$ GeneChip. BMC Genetics. 2007; 8: 79-84.

4. Philibert RA, Zadorozhnyaya O, Beach SRH, et al. A comparison of the genotyping results using DNA obtained from blood and saliva. Psyhciatr Genet. 2008; 18: 275-281.

5. Stockley RA and Campbell EJ. Alpha-1-antitrypsin genotyping with mouthwash specimens. Eur Respir J. 2001; 17: 356-359.

6. O Hansen TV, Simonsen MK, Nielsen FC, et al. Collection of blood, saliva and buccal cell samples in a pilot study on the Danish nurse cohort: comparison of response rate and quality of genomic DNA. Cancer Epidemio Biomark Prev. 2007; 16: 2072-2076.
7. Garcia-Closas M, Egan KM, Abruzzo J, et al. Collection of genomic DNA from adults in epidemiological studies by buccal cytobrush and mouthwash. Cancer Epidemio Biomark Prev. 2001; 10: 687-696.

8. Dawes C. Estimates, from saliva analyses, of the turnover time of the oral mucosal epithelium in humans and the number of bacteria in an edentulous mouth. Arch Oral Biol. 2003; 48: 329-336.

9. Lum L and Le Marchand L. A simple mouthwash method for obtaining genomic DNA molecular epidemiological studies. Cancer Epidemio Biomark Prev. 1998; 7: 719-724.

10. Heath EM, Morken NW, Campbell KA, et al. Use of buccal cells collected in mouthwash as a source of DNA for clinical testing. Arch Pathol Lab Med. 2001; 125: 127-133.

11. Feigelson HS, Rodriguez C, Robertson AS et al. Determinants of DNA yield and quality from buccal cell samples collected with mouthwash. Cancer Epidemio Biomark Prev. 2001; 10: 1005-1008.

12. Rudney JD and Chen R. The vital status of human buccal epithelial cels and the bacteria associated with them. Arch Oral Biol. 2006; 51: 291-298

13. Mulot C, Stucker I, Clavel J, et al. Collection of human genomic DNA from buccal cells for genetics studies: comparison between cytobrush, mouthwash and treated card. J Biomed Biotech. 2005; 3: 291-296.

14. Rylander-Rundqvist T, Hakansson N, Tybring G, et al. Quality and quantity of saliva DNA obtained from the self-administered Oragene method - a pilot study on the cohort of Swedish men. Cancer Epidemio Biomark Prev. 2006; 15: 1742-1745.

15. Zayats T, Young TL, Mackey DA, et al. Quality of DNA extracted from mouthwashes. PLoS ONE 2009, 4: e6165.

16. Cheng JR, Guan SF, Wang XL, et al. Feasibility of genetic polymorphism analysis using genomic DNA obtained from human buccal cells. Chinese J Cancer. 2005; 24: 893-897.

17. Ng DPK, Koh D, Choo SLG, et al. Effect of storage conditions on the extraction of PCR-quality genomic DNA from saliva. Clinica Chemica Acta. 2004; 343: 191-194. 